\title{
Skrining Lesi Prakanker Leher Rahim Dengan Pemeriksaan IV A
}

\author{
Screening For Find Early Asymtomatic Lesions Cervical Cancer With VIA Test \\ Sulastry Pakpahan ${ }^{1}$, Ruth DJ $^{2}$, Elly Sianturi ${ }^{3}$ \\ ${ }^{1}$ Prodi Tarutung, Poltekkes Kemenkes Medan, ${ }^{2}$ RSUD Tarutung, Kabupaten \\ Tapanuli Utara, ${ }^{3}$ Prodi Tarutung, Poltekkes Kemenkes Medan \\ (lastryp@gmail.com, ruthpakpahan17@gmail.com, ellysianturi@gmail.com)
}

\begin{abstract}
ABSTRAK
Indonesia menempati urutan kedua kasus kanker serviks terbanyak di dunia. Ironisnya 80\% dari penderita kanker serviks datang dalam stadium lanjut, padahal kanker ini dapat ditemukan pada tahap lesi prakanker dengan pemeriksaan IVA. Tujuan penelitian ini adalah untuk mengetahui skrining lesi pra kanker leher rahim melalui pemeriksaan IVA. Penelitian ini menggunakan metode observasional analitik dengan pendekatan cross sectional. Pengambilan sampel dilakukan dengan teknik consecutive sampling yaitu semua WUS yang datang ke Puskesmas Sipoholon untuk pemeriksaan IVA sejumlah 185 orang dan memenuhi kriteria inklusi berjumlah 156 orang. Hasil penelitian menunjukkan perubahan sel pada serviks berdasarkan hasil pemeriksaan IVA positif ditemukan lebih banyak pada wanita yang menikah pertama kalinya di usia $<20$ tahun $(63,6 \%)$, riwayat penggunaan kontrasepsi pil yaitu sebanyak (45,5\%) merokok aktif yaitu sebanyak $(9,13 \%)$, dan kurangnya pengetahuan tentang pencegahan kanker serviks (54,5\%). Hasil analisis Regresi logistik diperoleh variabel usia menikah, riwayat kontrasepsi, status merokok, dan pengetahuan tentang pencegahan kanker serviks secara simultan mempengaruhi hasil pemeriksaaan IVA sebesar 61,4 \%, sedangkan sisanya dipengaruhi oleh variabel lain di luar penelitian ini. Diperlukan upaya pencegahan kanker serviks pada wanita dengan menghindari faktor risiko diantaranya usia seksual/menikah dan melahirkan sebaiknya $>20$ tahun, menghindari paparan asap rokok dan penggunaan kontrasepsi hormonal jangka panjang.
\end{abstract}

Kata kunci : Lesi Prakanker Serviks, Pemeriksaan IVA, Skrining

\section{ABSTRACT}

In the case of cervical cancer, Indonesia is the second most cases of cervical cancer in the world. Ironically $80 \%$ of cervical cancer sufferers come in an late stage, even though this cancer can be found in the pre-cancerous lesion stage with VIA test. This study aimed to determine the screening precervical cancer through VIA test. This study used an analytic observational method with a cross sectional approach. Sampling was done by consecutive sampling technique, namely all female women who came to the Sipoholon Health Center for VIA test totaling 185 people and meet the inclusion criteria totaling 156 people. The results showed that cell changes in the cervix based on the results of a positive IVA test were found to be more in women who were married for the first time at $<20$ years of age (63.6\%), a history of use of oral contraceptives pill (45.5\%) was active smoking as much as $(9,13 \%)$, and a lack of knowledge about cervical cancer prevention (54.5\%). The results of logistic regression analysis showed that the variable age of marriage, history of contraception, smoking status, and knowledge of cervical cancer prevention simultaneously affected the results of the IVA test by $61.4 \%$, while the rest was influenced by other variables outside of this study. Efforts to prevent cervical cancer in women are needed by avoiding risk factors including sexual age / marriage and childbirth, preferably> 20 years, avoiding exposure to cigarette smoke and long-term use of hormonal contraceptives.

Keywords: Lesions Cervical Cancer, Skrining, VIA Test 
Sulastry Pakpahan, Ruth DJ, Elly Sianturi : Skrining Lesi Prakanker Leher Rahim ....

\section{PENDAHULUAN}

Kanker leher rahim (serviks) merupakan masalah kesehatan yang penting bagi perempuan di seluruh dunia. Kanker serviks menjadi penyebab kematian keempat pada wanita di seluruh dunia salah satunya adalah negara India merupakan negara penyumbang nomor dua kematian akibat Kanker Serviks yaitu sebesar 26\% (Society, 2016). Kanker serviks merupakan penyakit kanker dengan presentase kasus baru yaitu sekitar 14\%.(Bray et al., 2018) Menurut WHO tahun 2010, terdapat 530.000 kasus yang setiap tahun lebih dari 270.000 kematian terjadi akibat kanker serviks (IARC, 2010).

Di Indonesia prevalensi kanker leher rahim merupakan jenis kanker yang tertinggi pada perempuan. Kanker ini seharusnya dapat ditemukan pada tahap yang lebih dini, akan tetapi kanker ini lebih sering diketahui pada stadium lanjut (70\%) yang menyebabkan tingginya angka kematian. Kanker serviks juga merupakan kanker kedua terbanyak di Indonesia yang menyerang perempuan setelah kanker payudara. Jumlah kasus kanker serviks di Indonesia yang dilaporkan pada tahun 2016 mencapai 348.809 kasus.(Bott, 2014) Sementara menurut laporan Global Cancer Observatory di tahun 2018, diperkirakan terdapat 32.469 kasus per tahun kanker serviks di Indonesia, dengan angka kematian mencapai 18.279 orang. Angka ini yang membuat Indonesia menduduki urutan kedua kasus kanker serviks terbanyak di dunia (The Global Cancer Observatory, 2019).

Ironisnya 80 \% dari penderita kanker serviks datang dalam stadium lanjut, dan 94 \% pasien dari kasus tersebut meninggal dalam 2 tahun. Hal ini disebabkan karena infeksi HPV sering tidak memiliki gejala apapun pada stadium awal. Namun ketika gejala-gejala telah muncul, seperti pendarahan tidak wajar pada vagina, nyeri pada panggul, siklus menstruasi tidak teratur, nyeri saat berhubungan seksual, badan lemas dan berat badan turun, keputihan tidak normal dan salah satu kaki membengkak, menjadi gejala dan tanda kanker serviks telah memasuki stadium lanjut (Kemenkes RI, 2019).

Penyebab kanker leher rahim adalah Human Papilloma Virus (HPV). Virus ini ditemukan pada 95\% kasus kanker leher rahim. Setiap wanita beresiko terkena infeksi HPV onkogenik yang dapat menyebabkan kanker leher rahim. HPV dapat dengan mudah ditularkan melalui aktivitas s3eksual. Insiden kanker seviks dipengaruhi oleh banyak faktor risiko diantaranya kekebalan tubuh, penggunaan alat kontrasepsi, paritas, ras, polusi, nutrisi, dan pemakaian DES (dietilstilbestrol) (Bott, 2014).

Kanker leher rahim dapat ditemukan pada tahap sebelum kanker (Lesi Prakanker). Jika ditemukan pada tahap lebih dini dapat menurunkan angka kematian dan menghemat pembiayaan kesehatan yang sangat tinggi. Salah satu penapisan kanker 
serviks yaitu dengan Inspeksi Visual Asetat (IVA), yang merupakan pemeriksaan seluruh permukaan leher rahim dengan menggunakan asam asetat (Juanda \& Kesuma, 2015).

Program penapisan kanker leher rahim dan kanker payudara di Kabupaten Tapanuli Utara yang telah berlangsung dari tahun 2007 telah mampu menapiskan sebesar $21,6 \%$ dari seluruh wanita usia subur dan dengan target sebesar 80\%. Kecamatan Sipoholon merupakan salah satu kecamatan di Kabupaten Tapanuli Utara dengan jumlah penduduk sebanyak 23.910 jiwa, memiliki 2 Puskesmas yaitu Puskesmas Sitada Tada dan Puskesmas Situmeang Habinsaran. Berdasarkan data kedua Puskesmas tersebut, cakupan deteksi dini kanker serviks dengan metode IVA test pada tahun 2018 adalah sebanyak 185 orang dengan jumlah pasangan usia subur (PUS) 3.166 yang berarti hanya 5, 84\% PUS yang telah ikut pemeriksaan IVA test (Dinkes Taput, 2017).

Studi pendahuluan di Kecamatan Sipoholon diperoleh data bahwa cakupan pemeriksaan IVA test masih rendah, kemudian dilakukan penelusuran terhadap 30 orang wanita usia subur di Kecamatan Sipoholon sehingga diketahui bahwa alasan mereka tidak ikut pemeriksaan mayoritas karena kurangnya pengetahuan dan adanya rasa malu dan takut terhadap hasil pemeriksaan apabila ditemukan hasil pemeriksaan IVA positif. Tujuan penelitian ini adalah untuk mengetahui skrining lesi prakanker leher rahim dengan pemeriksaan inspeksi visual asetat (IVA) sebagai skrining awal kanker serviks.

\section{METODE}

Jenis penelitian ini adalah penelitian kuantitatif dan desain penelitian observasional analitik dengan pendekatan cross sectional (Notoadmojo, 2018), dimana peneliti melakukan observasi pada saat responden datang melakukan pemeriksaan, untuk mengetahui hasil pemeriksaan IVA dan penanganan yang dilakukan dengan pendekatan see and treatment. Pengambilan data menggunakan data primer yaitu lembar kuesioner berisi pertanyaan tertutup yang disusun oleh peneliti dan lembar hasil pemeriksaan IVA yang dilakukan. Penarikan sampel menggunakan teknik consecutive sampling yaitu semua wanita usia reproduktif yang datang ke Puskesmas Situmeang Habinsaran dan Puskesmas Sitada-tada untuk pemeriksaan IVA pada bulan Maret - Agustus berjumlah 156 orang yang memenuhi kriteria inklusi yaitu : 1) wanita berusia 16 - 50 tahun, 2) sudah pernah melakukan hubungan seksual, 3) belum pernah terdiagnosis kanker serviks 4) tidak sedang masa nifas, 5) tidak sedang mendapat pengobatan vaginal suppositoria, 6) bersedia menjadi responden. Metode analisis bivariate menggunakan Chi Square, sedangkan untuk uji linearitas menggunakan analisis Regresi linear logistik.. 
Sulastry Pakpahan, Ruth DJ, Elly Sianturi : Skrining Lesi Prakanker Leher Rahim ....

\section{HASIL}

Analisis ini digunakan untuk mengetahui apakah ada hubungan antara perubahan sel pada serviks dengan usia menikah berdasarkan hasil pemeriksaan IVA, yang diuraikan pada tabel berikut.

Tabel 1. Hubungan Usia Menikah Dengan Lesi Prakanker Leher Rahim Berdasarkan Hasil Pemeriksaan IVA

\begin{tabular}{|c|c|c|c|c|c|c|c|c|c|}
\hline Kategori & & Hasi & Pemeriks & an IV & Test & & Jml & $\mathrm{X} 2$ & $\rho$ \\
\hline Usia Menikah & $\begin{array}{c}\text { IVA } \\
\text { Negatif }\end{array}$ & $\%$ & Infeksi & $\%$ & $\begin{array}{c}\text { IVA } \\
\text { Positif }\end{array}$ & $\%$ & & & \\
\hline$<20$ tahun & 62 & 58,5 & 6 & 15,4 & 7 & 63,6 & 75 & & \\
\hline 20 - 35 tahun & 45 & 40,6 & 15 & 38,5 & 3 & 27,3 & 61 & & \\
\hline$>35$ tahun & 1 & 0,9 & 18 & 46,2 & 1 & 9,1 & 20 & 12,59 & $<, 05$ \\
\hline Jumlah & 106 & 100 & 39 & 100 & 11 & 100 & 156 & & \\
\hline
\end{tabular}

Usia menikah dikaitkan erat dengan usia pertama kali melakukan hubungan seksual dengan pasangan. Tabel 1. menunjukkan bahwa perubahan sel pada serviks yaitu terjadinya lesi pra kanker berdasarkan hasil pemeriksaan IVA positif ditemukan lebih banyak pada wanita yang menikah pertama kalinya di usia $<20$ tahun (63,6\%), sedangkan pada usia menikah 20-35 tahun sebanyak 27,3\% dan diatas 35 tahun sebanyak 9,1\%. Berdasarkan hasil analisis Chi Square dapat diketahui bahwa nilai chi square hitung >chi square tabel dapat disimpulkan H0 ditolak dan Ha diterima. Sehingga dapat diartikan bahwa terdapat hubungan antara lesi pra kanker dengan usia menikah ibu $(\rho<0,05)$ dengan tingkat keeratan hubungan pada kategori rendah.

Analisis ini digunakan untuk mengetahui apakah ada hubungan perubahan sel pada serviks dengan riwayat penggunaan kontrasepsi berdasarkan hasil pemeriksaan IVA, dapat dilihat pada tabel berikut:

Tabel 2. Hubungan Riwayat Kontrasepsi Dengan Lesi Prakanker Leher Rahim Berdasarkan Hasil Pemeriksaan IVA

\begin{tabular}{|c|c|c|c|c|c|c|c|c|c|}
\hline \multirow{2}{*}{$\begin{array}{c}\text { Kategori } \\
\text { Riwayat } \\
\text { penggunaan } \\
\text { kontrasepsi }\end{array}$} & \multicolumn{6}{|c|}{ Hasil Pemeriksaan IVA Test } & \multirow[t]{2}{*}{ Jml } & \multirow[t]{2}{*}{$\mathrm{X} 2$} & \multirow[t]{2}{*}{$\rho$} \\
\hline & $\begin{array}{c}\text { IVA } \\
\text { Negatif }\end{array}$ & $\%$ & Infeksi & $\%$ & $\begin{array}{c}\text { IVA } \\
\text { Positif }\end{array}$ & $\%$ & & & \\
\hline Pil & 62 & 58,5 & 10 & 25,6 & 5 & 45,5 & 77 & 11,07 & $<0,05$ \\
\hline Suntik & 38 & 35,8 & 16 & 41,0 & 1 & 9,1 & 55 & & \\
\hline Implan & 4 & 3,8 & 11 & 28,2 & 3 & 27,3 & 18 & & \\
\hline IUD & 2 & 1,9 & 2 & 5,1 & 2 & 18,2 & 6 & & \\
\hline Jumlah & 106 & 100 & 39 & 100 & 11 & 100 & 156 & & \\
\hline
\end{tabular}

Tabel 2 diatas, menunjukkan bahwa ibu yang melakukan pemeriksaan IVA Test berdasarkan riwayat kontrasepsi mayoritas pernah menggunakan pil KB sebanyak 77 orang, dan hasil test IVA positif ditemukan terbanyak pada kelompok riwayat penggunaan kontrasepsi pil yaitu sebanyak (45,5\%). Berdasarkan hasil analisis Chi 
Square dapat diketahui bahwa nilai hitung > nilai tabel dapat disimpulkan H0 ditolak dan Ha diterima. Sehingga dapat diartikan bahwa ada hubungan antara hasil pemeriksaan iva test dengan riwayat penggunaan kontrasepsi pada ibu $(\rho<0,05)$ dengan tingkat keeratan hubungan pada kategori rendah ( $\mathrm{r}=0.348)$.

Analisis ini digunakan untuk mengetahui apakah terdapat hubungan perubahan sel pada serviks dengan status merokok berdasarkan hasil pemeriksaan IVA, disajikan dalam tabel berikut:

Tabel 3. Hubungan Status Merokok Dengan Lesi Prakanker Leher Rahim Berdasarkan Hasil Pemeriksaan IVA

\begin{tabular}{|c|c|c|c|c|c|c|c|c|c|}
\hline Kategori & & Hasil & emeriks & an IV & Test & & Jml & $\mathrm{X} 2$ & $\rho$ \\
\hline Merokok & $\begin{array}{c}\text { IVA } \\
\text { Negatif }\end{array}$ & $\%$ & Infeksi & $\%$ & $\begin{array}{c}\text { IVA } \\
\text { Positif }\end{array}$ & $\%$ & & & \\
\hline Tidak merokok & 22 & 20,8 & 9 & 23,1 & 1 & 4,5 & 32 & & \\
\hline Pasif & 74 & 69,8 & 28 & 71,8 & 4 & 6,45 & 106 & 9,48 & $<0,05$ \\
\hline Aktif & 10 & 9,4 & 2 & 5,1 & 6 & 9,13 & 18 & & \\
\hline Jumlah & 106 & 100 & 39 & 100 & 11 & 100 & 156 & & \\
\hline
\end{tabular}

Pada tabel tabel 3, diketahui bahwa ibu yang melakukan pemeriksaan IVA Test dengan status merokok mayoritas dengan status merokok pasif, dan hasil test IVA positif ditemukan terbanyak pada kategori merokok aktif yaitu sebanyak (9,13\%). Berdasarkan hasil analisis Chi Square dapat diketahui bahwa nilai hitung > nilai tabel dapat disimpulkan bahwa terdapat hubungan antara perubahan sel serviks dengan hasil pemeriksaan iva test berdasarkan status merokok pada ibu $(\rho<0,05)$ dengan tingkat keeratan hubungan pada kategori sangat rendah ( $\mathrm{r}=0.158)$.

Analisis ini digunakan untuk mengetahui hubungan perubahan sel pada serviks dengan usia menikah berdasarkan hasil pemeriksaan IVA, disajikan dalam tabel berikut.

Tabel 4. Hubungan Pengetahuan Dengan Lesi Prakanker Leher Rahim Berdasarkan Hasil Pemeriksaan IVA

\begin{tabular}{|c|c|c|c|c|c|c|c|c|c|}
\hline Kategori & & Hasil & meriksa & IVA & Test & & $\mathbf{J m l}$ & $\mathrm{X} 2$ & pValue \\
\hline Pengetahuan & $\begin{array}{c}\text { IVA } \\
\text { Negatif }\end{array}$ & $\%$ & Infeksi & $\%$ & $\begin{array}{c}\text { IVA } \\
\text { Positif }\end{array}$ & $\%$ & & & \\
\hline Baik & 36 & 43,0 & 3 & 7,7 & 2 & 18,2 & 41 & & \\
\hline Cukup & 66 & 62,3 & 14 & 35,9 & 3 & 27,3 & 83 & 9,48 & $<0,05$ \\
\hline Kurang & 4 & 3,8 & 22 & 56,4 & 6 & 54,5 & 32 & & \\
\hline Jumlah & 106 & 100 & 39 & 100 & 11 & 100 & 156 & & \\
\hline
\end{tabular}

Dari tabel 4. menunjukkan bahwa ibu yang melakukan pemeriksaan IVA Test berdasarkan pengetahuan ibu tentang pencegahan kanker serviks di wilayah Kecamatan Sipoholon adalah dengan kategori pengetahuan baik (26,28\%), pengetahuan (cukup (53,20\%), pengetahuan rendah (20,51\%). Perubahan sel serviks dengan hasil IVA positif terbanyak ditemukan pada ibu dengan pengetahuan kurang (54,5\%). Hasil analisis Chi 
Square diketahui bahwa nilai hitung > nilai tabel dapat disimpulkan H0 ditolak dan Ha diterima. Sehingga dapat diartikan bahwa ada hubungan antara hasil pemeriksaan iva test dengan pengetahuan tentang kanker serviks pada ibu $(\rho<0,05)$ dengan tingkat keeratan hubungan pada kategori cukup kuat ( $\mathrm{r}=0.466)$.

Analisis multivariat dilakukan untuk mengetahui pengaruh variabel bebas (usia menikah, riwayat kontrasepsi, status merokok dan pengetahuan tentang pencegahan kanker serviks) secara bersama-sama dengan variabel terikat (perubahan sel serviks) berdasarkan hasil pemeriksaan IVA. Hasil analisis dengan menggunakan regresi logistik diperoleh hasil sebagai berikut:

Tabel 5. Regresi logistik variabel usia menikah, riwayat kontrasepsi, status merokok dan pengetahuan dengan lesi prakanker leher rahim melalui pemeriksaan IVA

\begin{tabular}{llcccccc}
\hline No & Faktor Risiko & Koefesien $\boldsymbol{\beta}$ & SE( $\boldsymbol{\beta})$ & $\boldsymbol{p}$ & $\begin{array}{c}\text { Adjusted } \\
\text { R Square }\end{array}$ & F & $\boldsymbol{p}$ \\
\hline 1 & Usia menikah & 0,072 & 0,081 & 0,142 & & & \\
2 & Riwayat kontrasepsi & 0,344 & 0,456 & 0,000 & 0,614 & 50,362 & 0,000 \\
3 & Merokok & 0,079 & 0,072 & 0,172 & & & \\
4 & Pengetahuan & 0,183 & 0,193 & 0,000 & & & \\
& Konstanta &,- 464 & 1,595 & & & & \\
\hline
\end{tabular}

Berdasarkan hasil analisis multivariat regresi logistik diperoleh bahwa variabel usia menikah, riwayat kontrasepsi, status merokok dan pengetahuan tentang pencegahan kanker serviks secara bersama - sama berpengaruh signifikan terhadap hasil pemeriksaan IVA dengan nilai $\mathrm{F}$ hitung $>$ Ftabel, diketahui $\mathrm{F}$ hitung $=50,362(\mathrm{p}<0,05)$. Hasil analisis regresi diperoleh nilai adjusted $R$ square 0,614, yang berarti variabel usia menikah, riwayat kontrasepsi, status merokok, dan pengetahuan tentang pencegahan kanker serviks secara simultan mempengaruhi hasil pemeriksaaan IVA test sebesar 61,4 \%, sedangkan sisanya dipengaruhi oleh variabel lain di luar penelitian ini.

\section{PEMBAHASAN}

Penularan virus HPV sebagai penyebab kanker leher rahim sangat bergantung pada hubungan seksual. Hal ini meningkat pada wanita yang melakukan hubungan seksual pada usia dini. Menikah di usia dini termasuk problem kesehatan reproduksi. Hubungan seksual merupakan awal risiko kehamilan, semakin muda umur menikah, maka semakin panjang waktu untuk bereproduksi. Oleh karena itu, usia pertama kali berhubungan seksual berkaitan dengan fertilitas. Data riset kesehatan dasar, diantara perempuan usia 10-54 tahun menikah pertama kali pada umur < 15 tahun (2,6\%) dan menikah pada umur 15-19 tahun (23,9\%).(RISKESDAS, 2018). Kanker mulut rahim atau 
kanker serviks adalah sejenis kanker yang 99,7\% disebabkan oleh human papilloma virus (HPV) onkogenik, yang menyerang leher rahim. Human papillomavirus (HPV) adalah virus yang paling sering dijumpai pada penyakit menular seksual dan diduga berperan dalam proses terjadinya kanker. Virus ini terutama ditularkan melalui hubungan seksual (Bott, 2014).

Pada penelitian ini menunjukkan bahwa perubahan sel serviks dengan hasil IVA positif lebih banyak ditemukan pada wanita yang menikah pertama kali pada usia di bawah 20 tahun (63,6\%; $\mathrm{p}<0,05)$. Faktor risiko seksual yang terkait dengan infeksi HPV dan kanker serviks adalah hubungan seksual pertama kali pada usia dini ( $>18$ tahun), dan riisko ini semakin meningkat dengan jumlah pasangan seksual yang berganti-ganti. ((Mcgraw \& Ferrante, 2014). Hal yang sama dengan penelitian Sulistiya pada tahun 2016 di RS Sardjito mengatakan bahwa wanita yang berhubungan seksual pertama kali pada usia $\leq 20$ tahun berisiko 2,41 kali lebih besar menderita kanker serviks dibandingkan dengan yang berhubungan seksual pertama pada usia $>20$ tahun.(Sulistiya et al., 2017) Semakin muda usia seorang wanita melakukan hubungan seks, kemungkinan terkena kanker serviks semakin besar. Hal ini didukung oleh penelitian Zarchi yang melakukan evaluasi faktor risiko kanker serviks pada wanita di rumah sakit Yazd-Iran dari tahun 2002-2009.

Penelitian menunjukkan bahwa dari 100 orang pasien kanker serviks, 84\% menikah pada usia di bawah 18 tahun dengan rata-rata usia pasien saat menikah adalah 15 tahun. Wanita yang melakukan hubungan seksual pertama kali pada usia 17-20 tahun berisiko 1,80 kali terkena kanker serviks, sedangkan wanita yang melakukan hubungan seks pertama kali pada usia $\leq 16$ tahun lebih berisiko 2,31 kali terkena kanker serviks. (Zarchi \& Akhavan, 2010). Penelitian lain yang sejalan yaitu penelitian Darmayanti tahun 2015 bahwa variabel umur awal melakukan hubungan seksual $(\mathrm{p}=0,00 ; \mathrm{OR}=4,5)$ memiliki hubungan dengan kejadian kanker leher rahim di RSUD Ulin Banjarmasin. (Darmayanti et al., 2015).

Menurut BKKBN pernikahan usia muda yaitu perkawinan yang dilakukan di bawah usia 20 tahun. Usia pertama kali berhubungan seksual bertepatan pada saat perkawinan, karena biasanya seseorang akan melakukan hubungan seksual jika sudah dalam ikatan perkawinan. Ketidakmatangan serviks secara biologis pada usia muda menjadi faktor risiko. Wanita yang mulai melakukan hubungan seksual pada usia $<20$ tahun lebih berisiko karena pada periode dewasa muda proses metaplasia sel skuamosa sangat 
meningkat sehingga berisiko terjadi transformasi atipik skuamosa meningkat yang kemudian menjadi neolpasia intraepitel cerviks (CIN).(Kemenkes RI, 2019)

Menikah di usia muda banyak disebabkan oleh faktor kebiasaan atau tradisi, adat, agama dan budaya, kemiskinan dan pemikiran terhadap stigma perempuan dewasa yang tidak menikah, kekhawatiran terhadap kehamilan atau pengenalan seksual pranikah. Selain itu perkembangan zaman di era saat ini membuat remaja memutuskan menikah muda, seperti legalitas hubungan seksual karena terlibat pergaulan bebas, mengakibatkan perilaku seksual di luar nikah juga meningkat, sehingga permasalahan usia pertama kali berhubungan seksual yang terlalu dini menjadi masalah kompleks.

Pada tabel 2 diketahui bahwa mayoritas ibu pernah menggunakan pil KB dan hasil test IVA positif ditemukan terbanyak pada kelompok riwayat penggunaan kontrasepsi pil yaitu sebanyak (45,5\%) dengan tingkat keeratan hubungan pada kategori rendah. Penggunaan kontrasepsi homonal dengan jangka waktu yang lama ( $>5$ tahun) merupakan faktor risiko dari infeksi HPV dan kanker leher rahim. Hal yang sama dengan penelitian Aziyah, dkk pada tahun 2017 menyebutkan bahwa penggunaan kontrasepsi hormonal yang lama yaitu lebih dari empat tahun dapat meningkatkan kejadian lesi kanker serviks sebesar 3,36 kali (p-value=0.008). (Aziyah et al., 2017)

Kontrasepsi hormonal seperti kontrasepsi oral dapat meningkatkan risiko kanker leher rahim karena jaringan leher rahim merupakan salah satu sasaran yang disukai oleh hormon steroid perempuan. Urban dkk tahun 2012 dengan sampel penelitian sebanyak 2182 dan perbandingan case control pada wanita di Afrika Selatan dengan hasil bahwa penggunaan kontrasepsi oral meningkatkan risiko kanker serviks sebesar 1,01 kali. Penggunaan kontrasepsi hormonal oral dan suntik jangka pendek dan panjang dikaitkan dengan peningkatan risiko kanker serviks, dengan penurunan risiko kanker ovarium dan endometrium (Zarchi et al., 2012).

Penggunaan kontrasepsi oral atau pil berhubungan dengan kejadian kanker serviks. Kontrasepsi oral atau pil mengandung hormon dalam bentuk kombinasi progestin dengan estrogen atau progestin. Kontrasepsi mencegah kehamilan dengan menghentikan ovulasi dan menjaga kekentalan lendir serviks sehingga tidak dapat dilalui oleh sperma. Risiko kanker serviks meningkat, terutama jika pil telah dipakai lebih dari 5 tahun. Namun wanita yang menggunakan kontrasepsi pil memiliki risiko kanker ovarium atau kanker rahim yang lebih rendah. Penelitian ini sejalan dengan penelitian Pramitha, et all yang mengatakan bahwa dibandingkan dengan wanita yang tidak pernah menggunakan kontrasepsi hormonal, mereka yang pernah menggunakan kontrasepsi hormonal selama 
1-4 tahun dan 5-25 tahun memiliki dua kali lipat dan 4,5 kali lebih besar untuk terkena kanker serviks (Paramita et al., 2010).

Kontrasepsi oral yang dipakai dalam jangka panjang yaitu lebih dari 5 tahun dapat meningkatkan risiko relatif seseorang menjadi 2 kali daripada orang normal. Proses tersebut diduga karena regulasi trasnkrip DNA virus dapat mengenali hormon dalam kontrasepsi pil, sehingga meningkatkan karsinogenesis virus. World health organization (WHO) melaporkan peningkatan risiko relatif pada pemakaian kontrasepsi oral/pil sebesar 1,19 kali dari normal yang meningkat seiring dengan lamanya pemakaian (WHO, 2013).

Riwayat penggunaan tembakau baik pada saat ini maupun di masa lalu dapat meningkatkan risiko karsinoma serviks sel skuamosa. (Mcgraw \& Ferrante, 2014). Pada penelitian ini pada tabel.3 menunjukkan bahwa terdapat hubungan yang signifikan antara perubahan sel serviks pada ibu dengan status merokok $(\rho<0,05)$ dengan tingkat keeratan hubungan pada kategori sangat rendah $(\mathrm{r}=0.158)$. Meskipun dalam penelitian ini secara statistik hubungan antara merokok aktif dengan hasil IVA test tergolong sangat rendah, namun wanita yang terkena paparan asap rokok (perokok pasif) memiliki risiko terkena kanker serviks. Penelitian yang sama dilakukan oleh Matsumoto di Jepang tahun 2010, menemukan bahwa perokok memiliki risiko dua kali lebih tinggi terkena infeksi HPV persisten dibandingkan dengan yang tidak pernah merokok (rasio odds, 2,50; interval kepercayaan 95\%, 1,30-4,81; $\mathrm{P}=$ 0,006) (Matsumoto et al., 2010).

Dewasa ini, merokok tidak hanya dilakukan laki-laki tapi juga wanita. Banyak wanita yang merokok tidak mengetahui bahwa kebiasaan merokok dapat memicu pertumbuhan kanker serviks. Rokok dapat menghambat respon imun yang seharusnya menghadapi virus HPV, Sel leher rahim yang terinfeksi HPV (yang sudah berisiko menjadi kanker) semakin mudah berubah menjadi kanker karena terekspos karsinogen yang ada pada rokok. Sebab, karsinogen sebagai zat yang menyebabkan kanker bekerja merusak DNA dari sel yang sudah terinfeksi kuman HPV.(Atika, 2019).

Penelitian Roura, et al, 2014 terdapat hubungan yang kuat antara sering merokok dan risiko kanker serviks hubungan yang kuat ditemukan antara sebagian besar ukuran merokok tembakau dan risiko neoplasia intraepitel serviks derajat 3/ karsinoma in situ dan kanker serviks invasif, setelah memperhitungkan paparan infeksi HPV di masa lalu.(Roura, 2014). Merokok mengganggu kejadian dan prevalensi infeksi HPV dan berhubungan dengan neoplasia intraepitel serviks dan CC invasif. Berbagai faktor tampaknya mengintervensi karsinogenesis serviks yang terkait dengan tembakau, 
terutama oleh efek karsinogenik lokal langsung dan imunosupresi lokal (FonsecaMoutinho, 2011).

Hubungan antara kebiasaan merokok dengan dampaknya terhadap risiko kanker leher rahim adalah Rokok dapat menghambat respon imun yang seharusnya menghadapi virus HPV sel leher rahim yang terinfeksi HPV (yang sudah berisiko menjadi kanker) semakin mudah berubah menjadi kanker karena terekspos karsinogen yang ada pada rokok. Sebab, karsinogen sebagai zat yang menyebabkan kanker bekerja merusak DNA dari sel yang sudah terinfeksi kuman HPV. Sehingga wanita yang merokok memiliki risiko 2 kali lebih besar dibandingkan wanita yang bukan perokok untuk mengalami kanker leher rahim. Hal ini juga berakibat yang sama terhadap perokok pasif karena terpapar zat kimia penyebab kanker yang ada pada rokok. Zat berbahaya ini terhirup lewat paru dan terbawa aliran darah ke seluruh tubuh (Atika, 2019).

Hasil penelitian pada tabel 4 menunjukkan perubahan sel pada serviks berhubungan dengan pengetahuan ibu tentang pencegahan kanker seviks $(p<0,05)$. Sebagian besar ibu dengan hasil pemeriksaan IVA test positif adalah ibu yang memiliki pengetahuan kurang tentang pencegahan kanker serviks (54,5\%). Berdasarkan hasil uji Chi Square didapatkan nilai hitung>nilai tabel, artinya terdapat hubungan hasil pemeriksaan IVA test dengan ibu yang mempunyai pengetahuan tentang kanker serviks, dengan tingkat keeratan hubungan pada kategori cukup kuat $(\mathrm{r}=0,466)$. Dalam melakukan perilaku pencegahan, dibutuhkan pengetahuan mengenai faktor resiko yang harus dihindari dan pemeriksaan deteksi dini serta peningkatan asupan nutrisi.

Perilaku yang didasari oleh pengetahuan akan lebih bertahan lebih lama daripada yang tidak didasari pengetahuan. Keikutsertaan seseorang dalam mengikuti pemeriksaan tes IVA besar pengaruhnya dipengaruhi oleh tingkat pengetahuan seseorang. Jika seseorang yang mempunyai tingkat pengetahuan yang baik diharapkan akan timbul minat dan benar-benar melakukan pemeriksaan deteksi dini kanker serviks, khususnya IVA. Semakin tinggi tingkat pengetahuan ibu, maka semakin baik kemampuan ibu dalam memahami informasi tentang deteksi dini kanker serviks, sehingga meningkatkan pengetahuannya tentang pencegahan dan deteksi dini kanker serviks.

Penelitian Lyimo, dkk mengatakan bahwa pengetahuan tentang kanker serviks dan pencegahannya berisiko 8,9 \% terhadap kejadian kanker serviks(OR = 8,90, 95\% CI = 2,14-16,03). (Lyimo \& Beran, 2012) Penelitian Getahun tahun 2013 di Northwest Ethiopia menemukan kejadian kanker serviks berhubungan dengan pengetahuan tentang kanker serviks (Getahun et al., 2013) Hal ini yang sama dengan penelitian Sulistiowati, 
dkk (2014) Pengetahuan responden tentang penyebab dan faktor risiko kanker serviks masih rendah sehingga mempengaruhi perilaku pemeriksaan deteksi dini juga masih rendah.

Setiap wanita memiliki risiko untuk menderita kanker serviks namun tidak semua wanita menyadari bahwa kanker serviks dapat diketahui secara dini dengan melakukan skrining dengan pemeriksaan IVA secara rutin minimal satu tahun sekali untuk melihat keadaan serviks, sehingga jika adanya gejala yang timbul mengarah keganasan dapat segera diobati. Hasil pemeriksaan IVA dipengaruhi oleh banyak faktor yang menjadi penyebab kejadian kanker serviks. Berdasarkan tabel 5 pada penelitian ini diperoleh nilai adjusted $R$ square 0,614, yang berarti variabel usia menikah, riwayat kontrasepsi, status merokok, dan pengetahuan secara simultan mempengaruhi hasil pemeriksaaan IVA test sebesar $61,4 \%$, sedangkan sisanya dipengaruhi oleh variabel lain di luar variabel yang diteliti.

Berdasarkan panduan penataksanaan kanker serviks terdapat 6 faktor risiko yang menyebabkan kanker serviks, yakni infeksi Human Papilloma Virus (HPV), merokok, mengalami HIV, menggunakan pil KB dalam waktu yang lama (5 tahun atau lebih), setelah melahirkan tiga anak atau lebih, dan memiliki beberapa pasangan seksual. (Kemenkes RI, 2015) Pada penelitian ini usia menikah, riwayat kontrasepsi, status merokok dan pengetahuan tentang pencegahan kanker serviks secara bersama - sama berhubungan dengan hasil pemeriksaan IVA $(\mathrm{p}<0,05)$. Setelah dilakukan pemeriksanan IVA di Kecamatan Sipoholon kemudian responden diberikan penanganan yang sesuai diantaranya hasil IVA positif dirujuk ke RSUD Tarutung untuk pemeriksaan lanjutan, penalaksanaan dilakukan tergantung pada diagnosis yang telah ditegakkan dari hasil pemeriksaan IVA. 1 orang dilakukan operasi histerektomi, lainnya diberikan therapy obat2an oleh dokter spesialis kebidanan dan kandungan.

Penatalaksanaan pasien yang dicurigai kanker bila ditemukan pasien yang dicurigai kanker serviks dilakukan biopsi. Jika pemeriksaan patologi anatomi mengkonfirmasi terdapatnya kanker serviks maka dirujuk maka dirujuk ke konsultan onkologi ginekologi untuk penatalaksanaan. Dan bagi yang hasilnya negatif dianjurkan untuk melakukan pemeriksaan IVA test 3-5 kemudian. Anjuran untuk melakukan pemeriksaan IVA bila : hasil positif (+) adalah 1 tahun sekali dan, bila hasil negative (-) adalah 5 tahun sekali. Penatalaksanaan IVA Positif Bila ditemukan IVA Positif, dilakukan krioterapi, elektrokauterisasi atau eksisi LEEP/LLETZ.(WHO, 2013) Krioterapi dilakukan oleh dokter umum, dokter spesialis obstetri dan ginekologi atau 
Sulastry Pakpahan, Ruth DJ, Elly Sianturi : Skrining Lesi Prakanker Leher Rahim ....

konsultan onkologi ginekologi. Elektrokauterisasi, LEEP/LLETZ dilakukan oleh dokter spesialis obstetri dan ginekologi atau konsultan onkologi ginekologi. Dan bila ditemukan pasien yang dicurigai kanker serviks dilakukan biopsi. Jika pemeriksaan patologi anatomi mengkonfirmasi terdapatnya kanker serviks maka dirujuk maka dirujuk ke konsultan onkologi ginekologi untuk penatalaksanaan (Kemenkes RI, 2015).

\section{SIMPULAN}

Berdasarkan hasil dari penelitian yang telah dilakukan dapat disimpulkan bahwa terdapat hubungan yang signifikan antara perubahan sel kanker dengan usia menikah, status merokok, riwayat kontrasepsi, dan pengetahuan tentang pencegahan kanker serviks berdasarkan hasil pemeriksaan IVA $(\mathrm{p}<0,05)$, dan variabel usia menikah dan status merokok mempunyai pengaruh yang lebih besar dibandingkan riwayat kontrasepsi dan pengetahuan. Perubahan sel pada serviks berdasarkan hasil pemeriksaan IVA pada ibu dipengaruhi oleh usia menikah, status merokok, riwayat kontrasepsi dan pengetahuan tentang pencegahan kanker serviks sebesar 61,4\%, dan selebihnya dipengaruhi oleh faktor lain yang tidak dimasukkan dalam penelitian ini.

\section{UCAPAN TERIMA KASIH}

Puji dan syukur peneliti panjatkan kehadirat Tuhan yang Maha Kuasa yang melimpahkan rahmat dan karunia-Nya, sehingga penulis dapat menyusun penelitian ini. Dalam kesempatan ini penulis mengucapkan terimakasih kepada Ka.UPT Puskesmas Kecamatan Sipoholon, dokter, bidan, kader dan semua pihak yang terkait dalam penelitian ini yang tidak dapat disebutkan satu persatu. Penulis menyadari masih banyak kekurangan dalam penyusunan penelitian ini maka saran dan kritik kami harapkan untuk kesempurnaan penelitian ini.

\section{DAFTAR PUSTAKA}

Atika, D. (2019). Dampak Merokok Terhadap Risiko Kanker. https://www.klikdokter.com/info-sehat/read/3622145/dampak-merokok-terhadaprisiko-kanker-leher-rahim

Aziyah, A., Sumarni, S., \& Ngadiyono, D. (2017). Faktor Resiko Yang Berhubungan Dengan Kejadian Kanker Servik; Studi Kasus Di RSUP Dr. Kariadi Semarang. Jurnal Riset Kesehatan. https://doi.org/10.31983/jrk.v6i1.2085

Bott, R. (2014). Data dan Informasi Kesehatan Situasi Penyakit Kanker. Igarss 2014, 1, 1-5. https://doi.org/10.1007/s13398-014-0173-7.2 
Bray, F., Ferlay, J., Soerjomataram, I., Siegel, R. L., Torre, L. A., \& Jemal, A. (2018). Global cancer statistics 2018: GLOBOCAN estimates of incidence and mortality worldwide for 36 cancers in 185 countries. CA: A Cancer Journal for Clinicians. https://doi.org/10.3322/caac.21492

Darmayanti, Hapisah, \& Kirana, R. (2015). Faktor-Faktor yang Berhubungan Dengan Kanker Leher Rahim di RSUD Ulin Banjarmasin. Jurnal Kesehatan, VI(2), 172177. poltekkes-tjk.ac.id/ejurnal/index.php/JK/article/download/102/92

Fonseca-Moutinho, J. A. (2011). Smoking and Cervical Cancer. ISRN Obstetrics and Gynecology. https://doi.org/10.5402/2011/847684

Getahun, F., Mazengia, F., Abuhay, M., \& Birhanu, Z. (2013). Comprehensive knowledge about cervical cancer is low among women in Northwest Ethiopia. BMC Cancer. https://doi.org/10.1186/1471-2407-13-2

IARC, (Internation Agency for Research on Cancer). (2010). World health organization international agency for research on cancer. Iarc Monographs On The Evaluation Of Carcinogenic Risks To Humans.

Juanda, D., \& Kesuma, H. (2015). Pemeriksaan metode IVA ( Inspeksi Visual Asam asetat ) untuk pencegahan kanker serviks. Jurnal Kedokteran Dan Kesehatan.

Kemenkes RI. (2015). Panduan Penatalaksanaan Kanker Serviks. Kementerian Kesehatan Republik Indonesia.

Kemenkes RI. (2019). Kasus Kanker di Indonesia. Databoks.

Lyimo, F. S., \& Beran, T. N. (2012). Demographic, knowledge, attitudinal, and accessibility factors associated with uptake of cervical cancer screening among women in a rural district of Tanzania: Three public policy implications. BMC Public Health. https://doi.org/10.1186/1471-2458-12-22

Matsumoto, K., Oki, A., \& Furuta, et all. (2010). Tobacco smoking and regression of low-grade cervical abnormalities. Cancer Science. https://doi.org/10.1111/j.13497006.2010.01642.x

Mcgraw, S. L., \& Ferrante, J. M. (2014). Update on prevention and screening of cervical cancer. 5(4). https://doi.org/10.5306/wjco.v5.i4.744

Notoadmojo, S. (2018). Metodelogi Penelitian Kesehaan. Indonesian Jourmal On Medical Science.

Paramita, S., Soewarto, S., Widodo, M. A., \& Sumitro, S. B. (2010). High parity and hormonal contraception use as risk factors for cervical cancer in East Kalimantan. Medical Journal of Indonesia. https://doi.org/10.13181/mji.v19i4.414

RISKESDAS. (2018). Riset Kesehatan Dasar 2018. Kementrian Kesehatan Republik Indonesia.

Roura, et all. (2014). Smoking as a major risk factor for cervical cancer and pre-cancer: Results from the EPIC cohort. International Journal of Cancer. https://doi.org/10.1002/ijc.28666

Society, A. C. (2016). Cervical Cancer What is cervical cancer American Cancer Society.

Sulistiya, D. P., Pramono, D., \& Nurdiati, D. (2017). Faktor-faktor yang berhubungan dengan kejadian kanker serviks di RSUP Dr. Sardjito Yogyakarta. Berita Kedokteran Masyarakat, 33(3), 125. https://doi.org/10.22146/bkm.17160

Taput, D. (2017). Profil Kesehatan Ibu dan Anak Kabupaten Tapanuli Utara Tahun 2017. http://www.ghbook.ir/index.php?name

The Global Cancer Observatory, G. (2019). Source: Globocan 2018. World Health Organization.

WHO. (2013). Guidelines for screening and treatment of precancerous lesions for cervical cancer prevention. WHO Guidelines. 
Sulastry Pakpahan, Ruth DJ, Elly Sianturi : Skrining Lesi Prakanker Leher Rahim ....

Zarchi, M. K., \& Akhavan, et all. (2010). Evaluation of cervical cancer risk-factors in women referred to Yazd-Iran hospitals from 2002 to 2009. Asian Pacific Journal of Cancer Prevention.

\begin{tabular}{|l|l|}
\hline Submission & 11 Desember 2020 \\
\hline Review & 19 Februari - 24 Maret 2021 \\
\hline Accepted & 25 Maret 2021 \\
\hline Publish & 12 April 2021 \\
\hline DOI & 10.29241/jmk.v7i1.590 \\
\hline Sinta Level & Tiga (3) Nasional Akreditasi \\
\hline
\end{tabular}

